\title{
The South Korean Blockbuster and a Divided Nation
}

\author{
Hyunseon Lee*
}

Since the late 1990s South Korean blockbusters have enjoyed global popularity. Although the term 'blockbuster' has been used almost synonymously with Hollywood films, we now identify blockbusters not only in Hollywood but also in other forms of 'world cinema' that make use of similar narratives and visual devices. The South Korean blockbuster could be a Hollywood-style one closely resembling the latter's style, or a 'big event film' appealing to domestic audiences, as the original use of the term 'blockbuster' suggests. ${ }^{1}$ 1960s South Korean cinema provides examples of big event films, comparable to Hollywood blockbusters of the same era, such as Shin Sang-ok's Sung Chunhyang (1961) and The Red

* Researcher and Senior Teaching Fellow, the Centre for Film Studies and the Centre of Korean Studies, SOAS, University of London

1 See Steve Neale, "Hollywood Blockbuster: Historical Dimensions," in: Julian Stringer (ed.): Movie Blockbusters (London and New York: Routledge, 2003): 4760. It has never been easy to clearly define the term 'blockbuster' itself because it has no essential characteristics. According to S. Neale, in the context of the cinema industry, its original English-language usage dates back to 1950s when the Hollywood epic Quo Vadis (1951) was described by US trade magazine Variety as a "box office blockbuster" (Ibid: 48): "Originally coined to describe a large-scale bomb in World War II, the term was taken up and used by Hollywood from the early 1950 s on to refer on the one hand to large scale productions and on the other to large-scale box-office hits" (Ibid: 47). See also Sheldon Hall and Steve Neale, Epics. Spectacles and Blockbusters: A Hollywood History (Detroit: Wayne State University Press, 2010). 
Scarf (1964). In the 1990s, when the domestic film market was dominated by Hollywood, The General's Son (1990), a gangster film set in the Japanese colonial period, and Sopyonje (1993), an art film about traditional folk music pansori, were produced by the director Im Kwon-taek. These are enlightening examples of Korean films attaining blockbuster-level status, as they broke box-office records for domestic movies at that time, and their commercial success contributed to the revival and re-emergence of the Korean film industry. Hollywood-style blockbusters, however, are relatively a new phenomenon, appearing in Korean cinema only since the late $1990 \mathrm{~s}^{2}$

I would like to point out that what differentiates South Korean blockbusters from the Hollywood ones is their engagement with Korean history and re-enactments of historical events, which is in part the reason for their success at the domestic box-office, in the global market, and at film festivals. My research concerns the way South Korean blockbusters remember, rewrite and archive historical events, exploring the question of why history and the nation are such common subjects, how these are depicted, and how Korean blockbusters differ from Hollywood films. In this paper, let me take a look into a few significant domestic blockbusters produced around 2000, in which the divided Korean nation plays an important thematic role, such as Shiri (1999) and Taegukgi - The Brotherhood of War (2004), both directed by Kang Je-kyu.

History, particularly forgotten national history, is a recurring issue in recent South Korean blockbusters, and several conditions have made this possible. The new generation of filmmakers in the 1990s - the so-called '386 generation' (then in their $30 \mathrm{~s}$, educated in the $80 \mathrm{~s}$, and born in the $60 \mathrm{~s}$ ) - had no experience of the Korean War, but they were equipped with an educational background in professional film schools. They also benefited from greater freedom from censorship. By 1996, the Motion Picture

2 Nikki J.Y. Lee and Julian Stringer, "Korean Blockbusters: Yesterday, Today and Tomorrow", in: Daniel Martin and Mark Morris (eds.): Discovering Korean Cinema (London: The Korean Cultural Centre UK, 2010, 58-69): 64-65. 
Law, which had been revised six times since 1961, was transformed into the Film Promotion Law in 1996, taking film production from the grasp of comprehensive state censorship. The democratic regimes of Kim Young-sam and Kim Dae-jung strongly promoted the cultural industry, and globalization. The US also put pressure on the Korean domestic market to open itself up for direct distribution of its products. The government came to have a weaker influence on film production, while larger companies (or chaebol) like Samsung, Daewoo and Lotte became major financiers of South Korean films, followed by the venture capital companies after 1998. Thus the young directors of the 386 generation have used their freedom to engage with history in an unprecedented way.

Beyond these factors, there is the nature of Korean history itself. Indeed, in the search for an interesting theme, film source or cultural content, especially one that appeals to broad audiences, including those over 30 and 40 years old, what can be more interesting, and dramatic, than a nation which is still divided? Moreover, the wounds of the Korean War and Cold War ideology are still found everywhere in Korean society and culture they are visible and invisible. All these factors contributed to the blockbuster status of certain films dealing with historical issues. These films have enjoyed not only domestic success but also international recognition, reaping commercial benefits while receiving considerable artistic recognition. They include JSA, Shiri, Taegukgi, but also Shilmido (2003) by Kang Woo-suk, and Welcome to Dongmakgol (Park Gwang-hyun, 2005), among others. ${ }^{3}$

The narratives of these films are based frequently on the trauma of national division, embodied in fratricide. The commercial success of Korean

3 Kang Je-kyu's film The Ginko Bed (1996) has been regarded as an advent of blockbuster, released on video with English subtitle, and The Soul Guardians (1998) by Park Kwang-chun as the first film marked and promoted as a Koreantype blockbuster, while Shiri has been regarded as the first successful South Korean blockbuster. Its production cost, sponsored by Samsung, was over 2.4 billion won, and had 5.78 million viewers within 1 year while Titanic had 4.7 million viewers (Korea Herald, July 21, 2000). 
War films around 2000 is partly grounded in the new modes of production, distribution, and exhibition, including marketing strategies and Hollywood aesthetic devices that possess transnational appeal (such as use of special effects, spectacles and narratives). Notably, in the film JSA, influences of film noir such as chiaroscuro cinematography are to be found, and in Shiri, the Hollywood influence can be seen in the spectaclecentered narrative structure, and its engaging Hollywood storytelling devices, such as the use of deadline, causality and redundancy. The boxoffice success of Shiri established a formula for the 'Korean-style blockbuster' and intensified the trend for the 'Korean-type blockbuster' as it marked out continuity and discontinuity from earlier South Korean films, particularly war cinema.

In contrast to the chase-driven scenes of Shiri, Taegukgi displays more spectacle-driven performances with massive explosions and combat scenes, and is often compared to Steven Spielberg's film Saving Private Ryan (1998). With the use of battles, male heroes, and masculinity as spectacle, the visual language reaches the level of the transnational and transcultural, similar to Hollywood blockbusters and other forms of world cinema. To a certain extent, therefore, we can see that Korean blockbuster films borrow genre and stylistic conventions from abroad.

However, South Korean blockbusters still must appeal to the emotions of Korean audiences, by focusing on the Confucian ideal of the family, particularly the theme of brotherhood, which remains fundamental in Korean culture and society. ${ }^{4}$ In Korean films, this theme recurs in that their characters are often biological brothers, soldiers-in-arms, or co-workers (as with the two protagonists in Shiri). These films however, usually

4 The production costs of Korean blockbusters have been escalating rapidly for the last decades, but adoption of blockbuster strategy for non-Hollywood industries involves a scaling down, and a "de-Westernizing process". See Choi Jinhee, The South Korean Film Renaissance: Local Hitmakers/Global Provocateurs (Middletown: Wesleyan UP, 2010): 33; Berry, Chris. “'What's big about the big film?' "De-Westernizing" the blockbuster in Korea and China," in Stringer (ed.), Movie Blockbusters: 217-229. 
begin with the family bonds broken, and in need of repair. In this way, the divided family is used as an allegory for the nation, the division of which is presented as tragic or absurd. A clear example of this is in Im Kwontaek's The Taebaek Mountain (1999), concerning the ideological conflict between communism and capitalism before and during the Korean War. In the film partly set during the Yeosu-Suncheon Rebellion in 1948, two brothers of a family in the South Jeolla province of Korea are fighting against one another, one being a leading Communist guerrilla fighter and the other a South Korean policeman.

A similar example can be found in Taegukgi, where the film functions as a kind of historical archive to be used to remember and overcome the wounds of the past. Taegukgi begins with the captivating spectacle of archival images of the excavation and forensic investigation of bones, skeletons, and bullets in a newly-discovered location for a battle during the Korean War almost 50 years later. Here, younger-generation Koreans are shown conducting archaeological research in order to identify the remains of the dead soldiers. A former soldier Jin-seok, forcibly drafted in the Korean War in 1950, has come to the archaeological site to identify his elder brother Jin-tae, also a soldier. Having waited five decades for his elder brother to return from the North Korean army, the confirmation of his death in the final moments of the film is a bitter ending. Leaving his brother back in the North Korean army became trauma for the younger brother, remembering the past itself as a painful process.

While enjoying the spectacle, then, Korean audiences are encouraged to remember that the North Koreans are human beings as well and they are their own forgotten brothers. Their own family members were killers and in turn killed by their "enemies" during the Korean War. These compelling tragic experiences constitute a form of post war memory and a means of historicizing national trauma. In these melodramatic examples of Korean war cinema, we generally find a positive sympathetic portrayal of North Korean soldiers, and this could be called a kind of humanization of Communists. We also find the celebration of Korean masculinity, where the male body performs Korean beauty, strength and attractiveness, 
though this heroic body ultimately suffers a tragic death.

Since the Korean War - a cold war - is an ongoing process, there can be neither a victory nor a happy end of the likes seen in Hollywood. The heroes of South Korean blockbusters mostly do not attain happiness at the end, even though they often seem to deserve it. This also marks an important difference from the celebration of victorious American masculinity in Hollywood films. The South Korean heroes are mostly tragic figures, e.g. the lost people; a lost loved woman and friend in Shiri, lost North and South Korean friends in $J S A$, lost brothers, friends and colleagues in Korean war films (such as Taegukgi, Welcome to Dongmakgol, 71: Into The Fire (John H. Lee, 2010), The Front Line (Jang Hoon, 2011). All these victims remain traumatized, just as the continuing Korean War remains an open wound in national history - a historical trauma. There is a sense that historical traumas need to be remembered, healed, and taught to the younger generation, as Yoon Je-kyoon tries to visualize in his most recent film International market - Ode to my Father (2014), a forgotten unknown history of the father.

Archiving historical narratives, keeping a collective memory of war and myth thereafter alive, unwritten history, unhealed historical wounds and traumas, and the nation - how better can these be collected, preserved and appreciated on a wide scale than with the 20th century mass media, film? In the era of globalizing culture, South Korean blockbusters enter with their hybrid characters, onto the global stage, with the celebration of a national male physique, and now also embrace the humanity of North Korean soldiers. Fetishizing the historical presentation of the male body, they also utilize and exploit Korean history and war, and function as part of a nationalistic agenda. Still, they have succeeded in entertaining millions at home and abroad. 